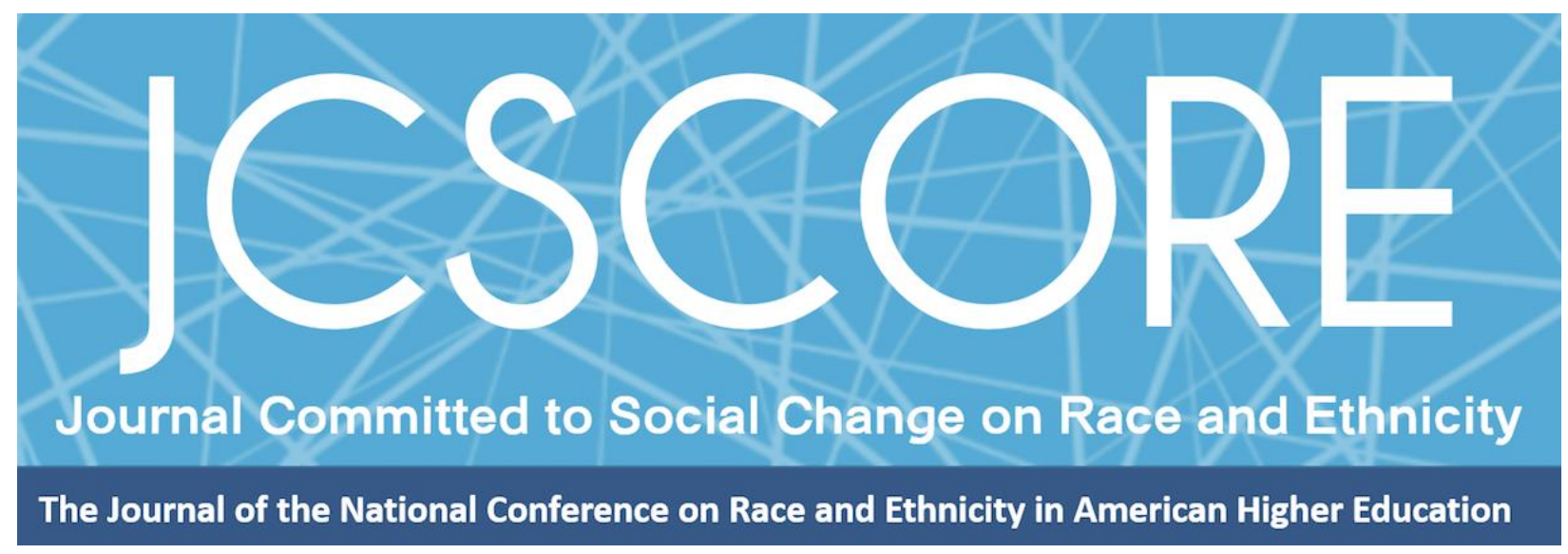

\title{
THE SOCIAL JUSTICE SYLLABUS DESIGN TOOL: A FIRST STEP IN DOING SOCIAL JUSTICE PEDAGOGY
}

\author{
Sherria D. Taylor \\ San Francisco State University 1 \\ Maria J. Veri 1 \\ Michele Eliason 1 \\ Jocelyn Clare R. Hermoso1 \\ Nicole D. Bolter1 \\ Juliana E. Van Olphen1
}

Journal Committed to Social Change on Race and Ethnicity Volume 5, Issue 2 | 2019

Copyright (C 2019 Board of Regents of The University of Oklahoma on behalf of the Southwest Center for Human Relations Studies.

Permission of the Publisher is required for resale or distribution and for all derivative works, including compilations and translations. Quoting small sections of text is allowed as long as there is appropriate attribution. 
Journal Committed to Social Change on Race and Ethnicity | Volume 5, Issue 2 | 2019

\title{
The Social Justice Syllabus Design Tool: A First Step in Doing Social Justice Pedagogy
}

\author{
Sherria D. Taylor \\ San Francisco State University 1 \\ Maria J. Veri 1 \\ Michele Eliason 1 \\ Jocelyn Clare R. Hermoso1 \\ Nicole D. Bolter1 \\ Juliana E. Van Olphen 1
}

Despite increased attention on social justice in higher education, underrepresented students often experience the classroom as unwelcoming and even hostile. Although theoretical and pedagogical research exists, what appears to be lacking are examples of concrete social justice pedagogy strategies that can be implemented in the classroom setting. This article describes the Social Justice Syllabus Design Tool (SJSDT) created to facilitate a greater emphasis on social justice in courses. Using an integrative framework and highlighting the focus areas of relationship, community, and process, the SJSDT offers a systematic approach to course re-design by which instructors can assess their classroom environment and course content. A syllabus that signals belongingness, growth mindset, communal goals, clear and positive expectations, and success-orientation assists in setting a welcoming tone that leads to greater student achievement and engagement. Such a syllabus may also help reduce the potential for triggering stereotype threat or other forms of alienation that affect student success among women and students of color in STEM programs. Feedback received from faculty who utilized the tool to revise their course syllabi are discussed, in addition to limitations and recommendations for future practice.

In response to the historic and systemic marginalization of women and students of color (SOC) in science, technology, engineering, and mathematics (STEM) fields in higher education, this article challenges college educators teaching these subjects to rethink and reframe their approach to developing course syllabi and content as a 
Journal Committed to Social Change on Race and Ethnicity | Volume 5, Issue 2 | 2019

practical first step in doing social justice pedagogy and developing classroom environments that foster inclusivity and student success. Some of the reasons that women and SOC experience increased levels of stress while attending college and subsequently leaves college, particularly in STEM fields, are the chilly and unwelcoming climate and feelings of being out of place (Clark \& Mitchell, Jr., 2019). To address these challenges, there has been a substantial increase in discourse emphasizing critical and social justice pedagogies as a means to increase academic success. Current discourse on social justice and critical pedagogy highlights the need for reflective and transformative practices among educators and relevant curriculum that draws upon the cultural wealth of students. Embedded within this discourse are numerous abstract principles to help educators reflect on and make paradigm shifts in their teaching, but moving from critique to actual change remains a major challenge noted within social justice pedagogy research overall (McArthur, 2010). This leaves many educators lacking the concrete tips, strategies, and tools necessary to transform their classrooms.

This article presents the Social Justice Syllabus Design Tool (SJSDT), an assessment tool and framework for educators in need of a practical first step in doing social justice pedagogy. The SJSDT provides a social justice framework by which the syllabus, often the first point of contact in a course, can be redesigned. This fills a gap in critical pedagogy research, as research focused on syllabi have been largely reflective and prescriptive in nature and lacking in practical assessment tools beneficial for the professional development of educators (McArthur, 2010). In laying the groundwork for the discussion of the SJSDT, this article begins with a brief overview of the challenges and experiences of women and SOC in STEM. Next, the article discusses the important 
Journal Committed to Social Change on Race and Ethnicity | Volume 5, Issue 2 | 2019

role of syllabi in these courses in creating an inclusive and success-oriented environment. Finally, the article concludes by offering syllabi and course-related strategies to improve the success of underrepresented students, feedback on the SJSDT, and a statement about the authors' positionalities.

\section{Challenges Faced by Underrepresented College Students in STEM}

Despite years of research and millions of dollars in federal funding aimed at understanding and ameliorating the underrepresentation of women and SOC in STEM fields, the retention and graduation rates of women and SOC continue to be significantly lower compared to their White peers. Since 2000, bachelor's degrees awarded to women in STEM declined by $8 \%$ on average, and while $61 \%$ of White students earned bachelor's degrees, only $13 \%$ of Latinx, $10 \%$ of Asian, $9 \%$ of Black, and . $5 \%$ of American Indian students completed their undergraduate programs (National Science Foundation, 2018). While these inequities are determined by multiple economic and structural factors, they are exacerbated by relational and environmental factors in the classroom setting.

\section{Hostile Campus Climate}

Many STEM educational environments are predominantly White and male (National Science Foundation, 2018). This lack of diversity often creates challenging racial climates and cultural mismatches in the classroom between the majority middleclass, independent, and hierarchical norms institutionalized in universities and the relatively interdependent, communal norms that SOC are often socialized with before college (Stephens, Townsend, Markus, \& Phillips, 2012). When underrepresented students perceive the academic environment as hostile, unwelcoming, discriminatory, or 
Journal Committed to Social Change on Race and Ethnicity | Volume 5, Issue 2 | 2019

biased, their comfort level, academic performance, satisfaction, and persistence are impacted negatively (King \& Ford, 2003).

Underrepresented students are especially attuned to climate characteristics and perceive campus climates as more racist and less accepting (Rankin \& Reason, 2005). For women of color in STEM the intersection of multiple identities presents additional challenges, as many report racism and sexism from faculty, isolation, exclusion from networking activities with faculty, and avoidance by White students in labs and classes (Johnson, 2012). In response, underrepresented students may diverge energy away from academic endeavors as a way to cope with hostile campus climates (Franklin, 2019).

\section{Challenges in Developing a Science Identity}

Hostile campus climates create challenges for underrepresented students in securing and maintaining a science identity - seeing one's self as a scientist (Espinosa, 2011). Women are typically less comfortable with identifying themselves as scientists. Recognition from faculty members is also more important for women as a component of science identity, and they typically feel the need to work harder than their peers to be recognized and have a lower sense of competence and self-efficacy (Williams \& George-Jackson, 2014). Trends for SOC show the weakest science identity (Hazari, Sadler, \& Sonnert, 2013). Even for SOC planning to go into STEM careers, low selfperceptions and experiences of disempowerment are more common. Because of these experiences, many underrepresented students once very interested in STEM, decide to leave the science pipeline while others persist.

\section{Invisibility}


Journal Committed to Social Change on Race and Ethnicity | Volume 5, Issue 2 | 2019

Experiences of invisibility in the classroom are also common among underrepresented STEM students. For some students, the experience of invisibility is described as being overlooked and ignored in the classroom, as well as experiencing a lack of validation of one's ethnic and racial experiences. For other students, experiences of invisibility are related to not seeing other students and faculty who look like them. For SOC, this lack of social and academic visibility equates to one's potential for success and confirmation that they do not belong (Strayhorn, Long, Kitchen, Williams, \& Stenz, 2013).

\section{Lack of Faculty of Support}

Although peers often provide social support, faculty support is the most important determinant of overall satisfaction and academic success for SOC in higher education, whereas it is not a significant predictor for White college students (Covington, Chavis, \& Perry, 2017). Students of color often perceive relationships with faculty more negatively, describing faculty as unfriendly, uncaring, intimidating, and unsupportive (Harris \& Wood, 2013). Due to these perceptions they find it difficult to approach faculty during times when support and help are needed and are less likely to enter into a mentoring relationship with faculty (Lundberg \& Schreiner, 2004). For women of color in STEM, a unique double bind with both racism and sexism persists, with them describing experiences in which they are discouraged by faculty from continuing in their major when seeking help with challenging course material, ignored by faculty, less likely to be recommended by faculty for academic opportunities, viewed as not being serious students, and receive little guidance compared to their peers (Espinosa, 2011). 
Journal Committed to Social Change on Race and Ethnicity | Volume 5, Issue 2 | 2019

\section{Negative Stereotypes}

Low expectations held by faculty due to negative stereotypes disparately impact SOC academic achievement (Strayhorn et al., 2013). This phenomena known as the Pygmalion Effect is a robust predictor of GPA (Boser, Wilhelm, \& Hanna, 2014). Even in the face of contradictory evidence, faculty often maintain low expectations of SOC (Solorzano, Ceja, \& Yosso, 2000).

Stereotype threat, a situational threat that arises when one's behavior threatens to conform to an existing negative stereotype of the particular group in which one identifies (Steele, 2011), is a unique phenomenon significantly impacting the performance of underrepresented students in STEM (Strayhorn et al., 2013). When they feel that they are being evaluated through the lens of those stereotypes or inadvertently perpetuating them, they are negatively impacted. There is also a feeling of increased pressure to display one's academic capabilities as a result of negative stereotypes about the groups in which they identify which results in higher levels of stress and negative attitudes about specific subjects. This plays out for women in higher level mathematics courses and physical sciences who feel that they are being evaluated differently than their male counterparts and for SOC who underperform relative to their ability on tests or if asked to report their race before taking a test (Steele, 2011).

\section{Fixed Mindset}

An instructor's mindset determines not only their expectations of students, but also their instructional practices and relationships with students (Brooks \& Goldstein, 2008). A fixed mindset views intelligence as a trait that is inherent and static, whereas a growth mindset views intelligence as something that can be developed with time, 
Journal Committed to Social Change on Race and Ethnicity | Volume 5, Issue 2 | 2019

practice, and instruction (Saucerman \& Vasquez, 2014). When instructors hold fixed mindsets, they are more likely to emphasize performance over process and believe that their efforts cannot support student improvement (Smith, Brumskill, Johnson, \& Zimmer, 2018). Instructor mindset also greatly impacts the mindsets students will hold and how they recover from academic setbacks (Blackwell, Trzesniewski, \& Dweck, 2007).

\section{Lack of Cultural Relevancy}

Negative experiences between faculty and underrepresented STEM students are linked to the countercultural values that persist in higher education. The meritocratic culture of science is often seen as difficult, hierarchical, individualistic, and intellectually superior to other academic fields, and for women of color this creates cultural conflicts and difficulty in navigating STEM environments that require them to complete certain tasks (i.e. dissecting animals), speaking up in learning spaces, and competing with peers for recognition, grades, and academic opportunities (Johnson, 2007). As a result of the cultural mismatch, many students feel as if they do not belong in college and experience uncertainty about the "right" way to act as college students. For the Native American STEM students observed by Jessi Smith and colleagues (2014), STEM did not appear to fulfill their communally-oriented desires to give back to and improve the quality of life for their tribal communities and was negatively associated with their performance and intentions to persist in the STEM field.

These findings suggest that faculty play a vital role in shaping students' perceptions of campus climates and overall sense of belonging. For SOC, often not having as much time for traditional college involvements or peer contact as their counterparts due to long commutes and financial and family responsibilities (Stieha, 
Journal Committed to Social Change on Race and Ethnicity | Volume 5, Issue 2 | 2019

2010), faculty are the ones who provide cues about whether a campus is inclusive and welcoming (Covington et al., 2017). Institutions, however, do little to assess and train faculty in principles of transformative practice even with years of research and theory to guide these processes. Discussions and research arguing for the transformation of higher education offer little in terms of concrete implementation strategies (McArthur, 2010). So, how can educators begin to transform their classrooms and address the aforementioned challenges faced by women and SOC in STEM? One suggestion is beginning with the first point of contact students have with a course, the syllabus.

\section{Why the Syllabus Matters}

A syllabus can be described as a guide to a course that outlines course policies, required texts, a schedule of assignments, and what will be expected of students. A syllabus, however, is much more as it not only describes the course, but also provides information about the instructor's personality, teaching style, and approachability (Sulik \& Keys, 2014). A syllabus offers a first impression of an instructor and the course, sets the tone for the entire class, and thus warrants careful scrutiny (Thompson, 2007). As Afros and Schryer (2009) noted, "instructors utilize the syllabus not only to manifest their membership in multiple discourse communities, but also to socialize students into (at least some of) them" (p.231).

If "teaching is in and of itself, a political act" (Leonard \& Moore, 2014, p. 76), then the syllabus is the manifesto of that politic. For faculty who are committed to social change and social justice education, there is much that can be conveyed in a syllabus that signals to students this commitment to justice. A social justice educator, theoretically, should be as interested in social justice issues in the classroom as in the 
Journal Committed to Social Change on Race and Ethnicity | Volume 5, Issue 2 | 2019

outside world, and would convey expectations of egalitarianism, cultural relevancy, focus on student success rather than failure, and offer concrete tips for success in the class, often called "insider knowledge" of the class (Sulik \& Keys, 2014, p. 152). Assessing the syllabus can therefore serve as a first step in doing social justice in the classroom. With that in mind, the Social Justice Syllabus Design Tool (SJSDT) was developed to support instructors in developing and assessing the extent to which their syllabi are informed by a social justice lens.

\section{The Social Justice Syllabus Design Tool's Theoretical Framework}

Several distinct and independent literatures on (a) syllabi best practices, (b) stereotype threat interventions, and (c) social justice pedagogy principles were reviewed in order to develop the SJSDT. From this review, an integrative social justice pedagogy framework that emphasizes teaching that directly addresses power and privilege issues, reduces stereotype threat, uses a variety of pedagogical strategies that increase sense of belongingness and communal values, models greater inclusivity (belongingness and identity as a researcher), and highlights the relevance of the content to students' personal lives was developed. This framework recognizes that students enter the classroom with very different experiences and expectations and may have general ability anxieties that are often triggered by the content. Thus, the instructor has an ethical duty to prepare a classroom experience that through both the content and pedagogical strategies focuses on student success. Table 1 describes the integrative social justice pedagogy framework themes that underlie the SJSDT. 
Journal Committed to Social Change on Race and Ethnicity | Volume 5, Issue 2 | 2019

Table 1 Integrative social justice pedagogy framework themes that underlie the SJSDT.

\begin{tabular}{|c|c|c|}
\hline Syllabus Best Practices & $\begin{array}{l}\text { Stereotype Threat } \\
\text { Interventions }\end{array}$ & $\begin{array}{c}\text { Social Justice Pedagogy } \\
\text { Principles }\end{array}$ \\
\hline $\begin{array}{l}\text { - Provides clear expectations } \\
\text { - Provides expectations of } \\
\text { - } \text { success } \\
\text { - } \text { Reduces jargon } \\
\text { students } \\
\text { - Includes communal } \\
\text { language } \\
\text { - Is learning-focused } \\
\text { - Promotes a growth mindset } \\
\text { - Is personal and less } \\
\text { - legalistic } \\
\text { - Points out professional and } \\
\text { personal relevance }\end{array}$ & $\begin{array}{l}\text { Eliminates stereotype- } \\
\text { triggering language } \\
\text { - Promotes a growth mindset } \\
\text { - Ties learning to values (i.e., } \\
\text { values affirmation activities) } \\
\text { - Promotes belongingness/ } \\
\text { inclusivity } \\
\text { - Includes stereotype threat } \\
\text { education }\end{array}$ & $\begin{array}{l}\text { - Emphasizes high } \\
\text { expectations } \\
\text { - Highlights social inequities } \\
\text { - Models a democratic and } \\
\text { inclusive approach } \\
\text { - Uses an intersectional } \\
\text { approach to the investigation } \\
\text { of problems } \\
\text { - Includes self-reflective } \\
\text { questions } \\
\text { - Directly discusses } \\
\text { power/privilege disparities }\end{array}$ \\
\hline
\end{tabular}

\section{Syllabus Best Practices}

Bawarshi (2003) labeled the syllabus as a "master classroom genre" (p. 119), and the assignments and content of the course as "meta genres." As the master classroom genre, the syllabus sanctions and regulates all that will occur within the classroom. As such, it can also be examined in the way any genre can be in how it generates and enforces interactions, subject positions, and practices instructors and students will perform throughout the course. The syllabus also has to attend to the tricky balance between meeting the needs of the students and the institution. It must be appealing to and motivating for students, structure their learning, and socialize them into the discipline, and, at the same time, be evaluated by senior colleagues and administrators in order to ensure course quality, professionalism, and teaching effectiveness. 
Journal Committed to Social Change on Race and Ethnicity | Volume 5, Issue 2 | 2019

The literature on syllabus design addresses issues of written language, grammatical structures, tone, and inclusivity from different perspectives. For example, Parson (2016) conducted a feminist discourse analysis of eight syllabi from STEM courses, looking for signs of gender bias. She found that most of the reviewed syllabi signaled a male-centric view of science by reinforcing ideas that knowledge is fixed, that power resides only in the instructors, and that students are passive recipients of knowledge. These value-laden ideas focus on the individual and foster a sense of competition rather than collaboration or collective support. These ideas were conveyed through language such as "students will" (directive, commands) versus "students may" or "students can," that imply some negotiation and choice. Parson also drew attention to the way in which pronouns set the tone for courses. Far more examples of "you" were found in the syllabi language (found 178 times) than "we" (14 times) or "us" (four times). Although there was no explicit gender language used in these syllabi, Parson demonstrated that the syllabi created a potentially hostile climate for women by promoting individualistic, masculine values. It could easily be argued that the same White male-centric language that Parson identified could be off-putting to students who are from more communal backgrounds, as are many SOC (Allen, Muragishi, Smith, Thoman, \& Brown, 2015). A more communal language that emphasizes relationship and connection in contrast to male-centric language that emphasizes individualism and hierarchy supports the creation of a collaborative and inclusive environment.

Other scholars, like Palmer, Wheeler, and Aneece (2016), come from a studentcentered learning approach and propose that the traditional syllabus is often contentfocused, whereas a learning-focused syllabus would be more engaging. They 
Journal Committed to Social Change on Race and Ethnicity | Volume 5, Issue 2 | 2019

developed a rubric and tested it with two groups of students to determine how students responded to these two types of syllabi. The content-focused syllabus made clear what students will and will not do in order to be successful in a course. They noted that these types of syllabi are "increasingly authoritarian and rule-infested to the detriment of student learning" (p. 37). Students who participated in the learning-focused syllabus group had significantly more positive perceptions of the syllabus and perceived the information included in the syllabus (i.e., instructor information and course objectives) as significantly more helpful than students who participated in the content-focused group. The learning-focused participants also had significantly more positive perceptions of the course and viewed the course as more relevant to their future careers. The learning-focused group also had significantly more positive perceptions of the instructor and believed the instructor would be more approachable, caring, encouraging, supportive, and helpful.

Similarly, Harnish and Bridges (2011) studied student reactions to syllabi that were written in either friendly or unfriendly language. They found that a friendly tone within the syllabi significantly led to student perceptions of the instructor as less cold, warm, more approachable, and more motivated to teach the course compared to students who read the unfriendly syllabus. In addition to perceptions of the instructor, students who read the friendly syllabus also viewed the class as less difficult than those who read the friendly syllabus. When a syllabus has too many policies and rules, and becomes more like a legal contract (Wasley, 2008), students may feel less motivated or constantly on the defensive. Similarly, the use of too much technical jargon that 
Journal Committed to Social Change on Race and Ethnicity | Volume 5, Issue 2 | 2019

represents new language to most students can be perceived as a sign of inaccessibility, with students seeing the course as too-difficult (Brown, 2006).

\section{Stereotype Threat Interventions}

The stereotype threat literature proposes that some students are vulnerable to negative stereotypes about academic performance, including women and SOC in math and science classes (Steele, 2011). Stereotypes can be triggered by language used in the syllabus and in the classroom if that language elicits a stereotype about women or ethnic groups' inferiority in math, science, or other white male-dominated fields. Interventions to reduce stereotype threat include the following: the addition of values affirmations exercises to the course curriculum (Cohen, Garcia, Purdie-Vaughns, Apfel, \& Brzustoski, 2009), the promotion of a growth mindset versus fixed mindset in the syllabus language used to discuss grading and assignments (Dweck, 2008), rolemodeling and promoting belongingness by inviting guest speakers in the field who are from underrepresented groups, including collaborative assignments and activities that promote belongingness (Spitzer \& Aronson, 2015), and teaching about stereotype threat directly (Johns, Schmader, \& Martens, 2005).

\section{Principles of Social Justice Pedagogy}

The central principles of social justice pedagogy are to highlight social injustices and interrogate power and privilege relationships in the syllabus, readings, and discussion of course topics (Convertino, 2016). The social justice-oriented classroom is designed to teach students to identify and disrupt societal power structures, thus the instructor needs to model a democratic, inclusive, and intersectional approach to problems in their discipline and create equitable and socially-just learning environments 
Journal Committed to Social Change on Race and Ethnicity | Volume 5, Issue 2 | 2019

(Adams \& Love, 2009). The social justice pedagogy literature tends to offer abstract principles and self-reflective questions to help instructors make paradigm shifts in their teaching, but has not yet provided practical tools for syllabus design (McArthur, 2010).

\section{The Development of the Social Justice Syllabus Design Tool}

The Social Justice Syllabus Design Tool (SJSDT) described in this paper has evolved since its first iteration in fall 2016. Some revisions were made to the tool based upon feedback from faculty who utilized the tool in redesigning their syllabi. Simple revisions included creating more of a process-orientation by changing checklist words "yes/no" to "reflection notes" and adding descriptive words that clarified specific concepts, i.e. adding "we and us" after communal language. The SJSDT was initially designed to support three faculty teaching undergraduate research methods and statistics courses in the redesign of their syllabi. The focus on these specific courses was due in part to their frequent status as gateway courses to upper division STEM courses and graduate programs, as well as educational research describing the debilitative effects of statistics anxiety on academic performance (Lalayants, 2012). These three faculty used the SJSDT to modify their syllabi and then engaged in group discussion with other research team members about additional modifications. In addition, the SJSDT was introduced and used in multiple workshops attended by faculty from diverse disciplines across a public university campus.

\section{Redesigning Syllabi Using the Social Justice Syllabus Design Tool}

The SJSDT provides faculty with supportive and concrete syllabus-revision strategies framed as reflective questions (see Appendix A). It is recommended that faculty review each question, assess whether or not that element is included in the 
Journal Committed to Social Change on Race and Ethnicity | Volume 5, Issue 2 | 2019

syllabus (i.e., yes or no), and write reflection notes about potential syllabus

modifications. To illicit a different perspective, it is also helpful to read syllabi from the perspective of a new student in the major. The SJSDT also provides a greater understanding of three primary focus areas that faculty committed to social justice may aim to address in order to begin transforming their classroom environments:

relationship, community, and process. The strategies that comprise each focus area were developed through the lens of the SJSDT's integrative framework, are supported by scholarly research, and seek to address the challenges faced by women and SOC in STEM.

\section{Relationship}

The SJSDT's focus on relationship emphasizes the messages that students receive from a syllabus about the type of relationship that is expected to occur between faculty and student. Here the roles of both faculty and students are understood. Relationship-oriented issues related to cultural mismatches, perceived lack of faculty support, and the perception of faculty as cold and distant, to name a few, have a significant impact on the academic success of women and SOC in STEM and may set an unsupportive tone even before the first day of class.

Student-centered syllabus. An impactful syllabus design strategy that addresses relationship is creating a student-centered syllabus. A student-centered syllabus focuses on providing clear rationales for assignments, avoiding busy work, validating students' potential feelings of anxiety in a particularly challenging course, and

providing learning tools and supportive campus resources that include one's availability to students (Thompson, 2007). For example, a statement such as "many students come 
Journal Committed to Social Change on Race and Ethnicity | Volume 5, Issue 2 | 2019

into this class with some concern about the math component; we will have many ungraded practice exercises to help you learn these skills" can be included in order to validate potential feelings of math anxiety. This particular syllabus design strategy helps create an environment in which the faculty's support of students is prioritized, in addition to the importance of learning course content.

Syllabus language. Another relationship-oriented strategy is attention to language. If the syllabus for a course is intended to be grounded in social justice but is written in the traditional content-focused style, it sends a mixed message to students and may inadvertently promote values of hierarchy and individualism. Within a syllabus, hierarchy and individualism can be conveyed by the misuse of personal pronouns, modal verbs, imperative mood, and negations (Baecker, 1998). Writing in the firstperson voice ( / or we; me or us) and using non-triggering language gives a syllabus agency and clarifies accountability. Describing the class experience democratically and using communal language (Thompson, 2007) such as we and us versus you and I is also seen as more egalitarian than you or third person constructions (Parson, 2016). It is important to note, however, that special attention must be paid to context when using we as its misuse can "blur the distinction between power and solidarity, and, in fact, allow power to be expressed as solidarity" or as "false or coercive we" (Baecker, 1998, p. 60). That is, the instructor whose behavior is not collaborative or student-centered negates the promise of the we language on the syllabus and may create a sense of distrust among students. A statement such as "tapping into your own personal experiences in community, we will generate ideas for collaborative strategies to engage 
Journal Committed to Social Change on Race and Ethnicity | Volume 5, Issue 2 | 2019

communities in improving their health" could be added as an example of communal language.

Modal verbs refer to those that are compulsory, such as must, will, and should, compared to those that imply more choice and negotiation, such as can and may. Imperative mood is defined by Baecker (1998) as those short directive commands often found in syllabi, such as "Come to class prepared to discuss readings" and "Notify the instructor of absences before they happen." These terse communications have a cold and sometimes even threatening tone. Negations focus on aspects that lead to failure and may be framed as "Never leave homework in my mailbox" or "Don't expect to negotiate for higher grades." Finally, power and authority can be signaled in various other ways, from a high authority statement such as "Late homework will not be accepted" to a softer version that explains why, such as "Because we will discuss the answers in class, I cannot accept late assignments." Highlighting text, underlining, all caps, bolding the pronouncements (e.g., NO CELL PHONES ALLOWED!) can also be off-putting to students. When the emphasis is on the rules and policies, the message to students is rather condescending and cold, and implies that faculty are focused on enforcing rules. An additional example of this around phone usage is "research has shown that being interrupted by a cell phone ringing or vibrating disrupts attention for more than ten minutes. Therefore, I request that you turn off both the ringer and vibration functions during class." Similarly, a syllabus laden with jargon and technical terms may highlight the disparity between faculty (experts) and students (novices).

List of student and instructor expectations. Sections can also be included in the syllabus that detail the instructor's expectation of the students as well as the 
Journal Committed to Social Change on Race and Ethnicity | Volume 5, Issue 2 | 2019

students' expectations of the instructor and can be framed as more engaging questions (Palmer et al., 2016). A section entitled, "What do I expect of you?", can underscore for students what their responsibilities are in meeting the course learning outcomes. In another section, "What can you expect of me?", instructors can disclose their own roles and responsibilities in supporting students in meeting the learning outcomes. This language helps show students that instructors take responsibility for their effort and behavior in the class, further interrogating the hierarchical power differentials between the instructor and students and reinforcing an egalitarian social norm in the classroom.

\section{Community}

The SJSDT's focus area of community highlights the way a syllabus either promotes or inhibits a collaborative and inclusive environment. Sense of community and belongingness are linked with college persistence, and students who report validating experiences in higher education are also less likely to report experiences of discrimination and bias (Hurtado, Alvarado, \& Guillermo-Wann, 2015). By intentionally focusing on the ways in which a syllabus promotes a welcoming and inclusive environment, challenges such as hostile campus climates, invisibility and isolation, lack of cultural relevancy, stereotype threat, and barriers to establishing a science identity can begin to be addressed from the first day of class.

Instructor information. Inclusivity, warmth, and the honoring of individual cultural wealth can be modeled by a section often overlooked in syllabi, instructor information. The contact information section can be written as a narrative where instructors tell their story briefly—who they are and about their teaching, scholarship, and practice experiences that relate to the course. Embedded in the introduction would 
Journal Committed to Social Change on Race and Ethnicity | Volume 5, Issue 2 | 2019

be their contact information presented in a more inviting way to students. The instructors can also state their preference for how students should contact them or request an appointment and provide a rationale behind their preference. For instance, rather than say, "No walk-ins please!", an instructor can say, "Please set up an appointment before coming to meet me for student hours. This will give me time to prepare for our meeting and will avoid double-booking."

Course description. The course description section can be written in a more engaging style and be retitled, "What is this class about?" Instructors may also describe what the course objectives and learning outcomes are, what topics and learning activities the students will undertake, and how the class is aligned with the program learning outcomes of their major and the goals of their profession. Particular courses (i.e. research methods, statistics, math), along the STEM academic pathway are often approached with feelings of anxiety, apprehension, and lack of self-confidence (Lalayants, 2012). In this section of the syllabus, instructors can acknowledge common challenges that students may face in understanding and applying the content of the class, while also reassuring them that such challenges can be overcome through collaborative learning and the egalitarian culture that will be fostered in class.

Course descriptions are also more meaningful when the course is described as relevant to students' future occupations, personal lives, goals for community transformation, and professional ethics (Adams \& Love, 2009; Thompson, 2007). Emphasizing the social justice implications of the class, the profession's commitment to social justice, and personal relevancy help to create a sense of buy-in for students and provide a means by which students better understand a course's purpose and potential 
Journal Committed to Social Change on Race and Ethnicity | Volume 5, Issue 2 | 2019

value for their lives, communities, and future professions. Reminding students that math and science skills are learned with practice and through getting feedback also helps to build a growth mindset.

Course content. The inclusion of guest speakers, films, or activities that introduce students to other students and professionals from diverse sociocultural backgrounds helps generate a sense of belongingness in the classroom and the field (Spitzer \& Aronson, 2015). Additionally, ensuring diverse groups are represented among the authors of course readings and materials is a complementary strategy that supports students who may otherwise feel invisible (Spitzer \& Aronson, 2015). Finding ways to explicitly integrate social justice principles into classroom topics models doing social justice in STEM and also provides an opportunity for students to see how content can be used to give back to their communities.

A democratic, collaborative approach to developing a course is an additional strategy used to create and sustain a sense of community (Edwards, 2010). Scheduling time for students to develop community agreements, determine discussion topics, lead class discussions, and submit work of their own choosing are ways for faculty to negotiate authority and empower students (McWilliams, 2015). For example, one assignment may be for a small group of students to choose a topic related to a particular unit, select a reading to share with the class, or facilitate an experiential activity relating to a topic. When a course is democratically developed and implemented, students feel seen and the course experience reflects who they are and what they value. 
Journal Committed to Social Change on Race and Ethnicity | Volume 5, Issue 2 | 2019

Syllabus language. Syllabus language can also promote community when language that is warm and inviting is used rather than technical jargon and language that reads like legal documentation. Using easily understood language instead of technical, legalistic terms and providing definitions of more technical terms in the syllabus decreases the likelihood of students feeling alienated by new and unfamiliar language (Sulik \& Keys, 2014; Thompson, 2007). Identifying legalistic areas of the syllabus that may feel distancing can be accomplished by assessing if each of the rules included is truly necessary for students' success (Harnish \& Bridges, 2011; Wasley, 2008). Additionally, a careful review for syllabus language that might trigger stereotype threat by comparing various groups' skills, ability levels, or other differences (Spitzer \& Aronson, 2015) and indicating in assignments, readings, and even scheduled topics how power and privilege might be played out are helpful strategies in achieving the goals of establishing and protecting a sense of community. For example, a unit labeled "Educational disparities based on race" might be more triggering than one labeled "How does institutional racism affect the educational experiences of students of color?"

\section{Process}

The SJSDT's focus area, process, draws attention to an instructor's norms, values, and expectations of how learning can and will occur which impact how faculty regulate emotions in the classroom, judgements about student behaviors, and grading outcomes (Brooks \& Goldstein, 2008). A focus on process supports faculty in assessing the success-orientation of a syllabus and identifying where in the syllabus growth mindset is promoted. Describing the course in a success-oriented way and knowledge and skills as learned rather than fixed supports students in seeing the classroom as a 
Journal Committed to Social Change on Race and Ethnicity | Volume 5, Issue 2 | 2019

nonjudgmental setting in which growth is the larger goal rather than perfection. A statement such as "I have found that students who complete the readings before class are better equipped to participate in class discussions, integrate the readings with the lectures, and do better on exams" is success-oriented as opposed to the common imperative "complete the assigned readings before class."

Course objectives and learning outcomes. The course objectives and learning outcomes section can be re-written with a growth mindset as opposed to a fixed mindset as well. Learning outcomes are stated not just as ends in themselves but as learning processes that students will go through. A section entitled, "What do I need to do and read to be successful in this course?", will help clarify to students what their own responsibilities are in achieving the learning outcomes and being successful in class. It also clarifies for students how the assigned and required readings, as well as the learning activities, help meet the course's learning outcomes.

List of assignments and grading policy. A listing of assignments and grading policies can be presented as a narrative that explains the rationale behind the assignments and how they build upon one another to meet the learning outcomes. Instead of using punitive language to emphasize deadlines and list penalties for late submissions, the syllabus can explain how assignments are scaffolded and how turning in assignments by their deadlines is critical to meeting the learning goals. For example, instructors may include a statement such as, "You must turn in your paper on time. No late papers will be accepted, and you will receive a 0 on the assignment.", in hopes that the students' knowledge of the penalty will compel them to turn the assignment in on time. However, an instructor might say instead, "You will want to turn in the assignment 
Journal Committed to Social Change on Race and Ethnicity | Volume 5, Issue 2 | 2019

by the deadline so you can get timely feedback on your progress toward your final paper." This language clarifies to the students that the deadline is not arbitrary but instead is important to their success and that prior assignments build up to the final paper or exam. In addition, offering low-stakes assignments encourages knowledge and skill acquisition and assists in creating a success and growth culture (Dweck, 1999). The syllabus may note "there will be ungraded activities in class that are designed to help you practice new skills before you are graded on them."

Course outline. A more creative way of presenting the list of topics and modules for the class would be to address the question, "What questions will we explore?" In so doing, students will have a better sense of the context behind the topics covered, the sequencing of topics, and how they connect to the course objectives and learning outcomes. Labeling the content as "questions" instead of "topics" reinforces a growth mindset. For example, instead of listing "sampling techniques" as the topic, posing a question like "How does the way we select participants for a research study affect the quality of the findings?" The use of questions is akin to Freire's (2018) problem-posing approach to education that fosters critical thinking.

Course content. The actual teaching of growth mindset theories also has significant impact on student engagement and grades for underrepresented students (Aronson, Fried, \& Good, 2002). Compared to their peers, SOC show significantly more enduring and positive changes in their attitudes about intelligence and improvements in their academic profiles when there is an intentional focus on teaching growth mindset as part of a course.

Syllabus Redesign Impressions, Challenges, and Recommendations 
Journal Committed to Social Change on Race and Ethnicity | Volume 5, Issue 2 | 2019

The SJSDT offers instructors evidence-based suggestions for reflecting on their current syllabi and revising syllabi content in order to align with the principles of social justice pedagogy in order to be more student-centered, increase sense of belonging, and reduce stereotype threat in the classroom. As the first step in doing social justice pedagogy, the syllabus is an effective way to convey messages about relationship, community, and the learning process. The syllabus frames the class content and process, informs the learning environment, and plays a pivotal role in shaping the instructor-student relationship that is key to fostering student inclusion, engagement, motivation, and safety. Feedback from workshop participants at the authors' university indicates that the SJSDT is a useful tool for reflective teaching practice and identifying strategies for doing social justice pedagogy. Participants described it as "user friendly" and encouraging "critique of documents without judgment." One workshop participant explained, "it provides a structure for review and accountability." Similarly, others noted it as being straightforward, concrete, and practical. The most rewarding outcome of the workshops was the participants' enthusiastic commitment to redesigning their course syllabi using the SJSDT. With regard to its overall purpose in shifting classroom culture, feedback from individuals who have used the SJSDT has indicated great appreciation for its emphases on growth mindset, relevancy, validating student anxiety, belongingness, and success orientation. For example, one instructor liked the "focus on inclusive language and on community building within the classroom," while another shared, "I love having something that opens my eyes in a different way."

Syllabus redesign does not come without challenges. One challenge noted by instructors was balancing the use of more social justice-oriented language in the 
Journal Committed to Social Change on Race and Ethnicity | Volume 5, Issue 2 | 2019

syllabus with the need to comply with the university's required standard policy language. The latter tends to be triggering for students with boilerplate text that underscores the institution's registration and grading policies in harsh, punitive language. Instructors who were willing to revise their syllabi to use more engaging and inclusive language felt constrained by the triggering language of the university's required standard text. In our own college, we were able to negotiate with the office that drafts these policy statements to use some of the same principles we used in the syllabus redesign tool.

Another limitation has to do with how instructors define social justice and, by extension, a social justice-oriented syllabus. As a contested notion, social justice is defined and understood differently by people. There are varying theories of social justice informed by different academic disciplines, value systems, ideologies, and belief systems. While some proponents of the SJSDT are in consensus about defining social justice pedagogy as addressing power and privilege in the classroom and linking these to structural oppression, other instructors may subscribe to different definitions of social justice and thus question the social justice assumptions of the SJSDT. These instructors may think that triggering language may not necessarily be considered antithetical to their definition of social justice. For instance, when addressing plagiarism, some instructors may feel strongly about intellectual dishonesty being a form of social injustice. Thus, these instructors believe that using strong and triggering language may be necessary to make students understand the seriousness of this act. Others may believe that social justice education is inherently triggering and that creating some level of discomfort is necessary for transformational learning. We would argue that this 
Journal Committed to Social Change on Race and Ethnicity | Volume 5, Issue 2 | 2019

triggering might be unavoidable or even necessary in some discussions and readings, but that the syllabus need not be triggering.

The SJSDT was initially developed for redesigning baccalaureate health and social sciences research methods courses, often perceived as gateways to graduate studies and advancement in STEM fields but has since been utilized by instructors from many different disciplines. This paper sought to introduce the SJSDT as a useful tool for faculty who are committed to social justice in the classroom but lack concrete strategies and feel overwhelmed by where to begin. Based on existing literature and user feedback, the SJSDT is a tool by which instructors can engage in reflective teaching practice, begin to address the challenges faced by underrepresented students, and move towards the goal of institutional transformation.

While the SJSDT effectively enables faculty to reflect more intentionally on how to incorporate social justice principles in their syllabi, one caveat identified is the requirement to also include institutional policies often written in punitive language. This conflict underscores the need to reform higher education institutional practices and thinking around social justice pedagogy and to develop initiatives to align university policy language with the tenets of social justice. For example, at our university we were able to leverage the positive, enthusiastic reception of the SJSDT at our workshops into additional university-wide presentations and the revision of one college's standard wording policy for all syllabi. Doing these things in tandem will ensure sustained support for social justice pedagogy and provide the foundation for an ecological process of transformation visible both in the classrooms and within the halls of administration. 
Journal Committed to Social Change on Race and Ethnicity | Volume 5, Issue 2 | 2019

\section{References}

Adams, M., \& Love, B. J. (2009). Social justice education: Inviting faculty to transform their institutions. In K. Skubikowski, C. Wright, \& R. Graf (Eds.), Social Justice Education: Inviting Faculty to Transform Their Institutions (pp. 3-25). Sterling, VA: Stylus Publishing, LLC.

Afros, E., \& Schryer, C. F. (2009). The genre of syllabus in higher education. Journal of English for Academic Purposes, 8(3), 224-233.

Allen, J. M., Muragishi, G. A., Smith, J. L., Thoman, D. B., \& Brown, E. R. (2015). To grab and to hold: Cultivating communal goals to overcome cultural and structural barriers in first generation college students' science interest. Translational Issues in Psychological Science, 1(4), 331-341.

Aronson, J., Fried, C. B., \& Good, C. (2002). Reducing the effects of stereotype threat on African American college students by shaping theories of intelligence. Journal of Experimental Social Psychology, 38(2), 113-125.

Baecker, D. L. (1998). Uncovering the rhetoric of the syllabus: The case of the mission "I." College Teaching, 46(2), 58-62.

Bawarshi, A. S. (2003). Genre and the Invention of the Writer: Reconsidering the Place of Invention in Composition. Logan, Utah: Utah State University Press.

Blackwell, L. S., Trzesniewski, K. H., \& Dweck, C. S. (2007). Implicit theories of intelligence predict achievement across an adolescent transition: A longitudinal study and an intervention. Child Development, 78(1), 246-263.

Boser, U., Wilhelm, M., \& Hanna, R. (2014). The Power of the Pygmalion Effect. Retrieved from Center for American Progress website: https://files.eric.ed.gov/fulltext/ED564606.pdf

Brooks, R., \& Goldstein, S. (2008). The mindset of teachers capable of fostering resilience in students. Canadian Journal of School Psychology, 23(1), 114-126.

Brown, B. A. (2006). "It isn't no slang that can be said about this stuff': Language, identity, and appropriating science discourse. Journal of Research in Science Teaching, 43(1), 96-126. 
Journal Committed to Social Change on Race and Ethnicity | Volume 5, Issue 2 | 2019

Clark, I., \& Mitchell, Jr., D. (2019). Exploring the relationship between campus climate and minority stress in African American college students. Journal Committed to Social Change on Race and Ethnicity, 4(1), 66-95.

Cohen, G. L., Garcia, J., Purdie-Vaughns, V., Apfel, N., \& Brzustoski, P. (2009).

Recursive processes in self-affirmation: Intervening to close the minority achievement gap. Science, 324(5925), 400-403.

Convertino, C. (2016). Beyond Ethnic Tidbits: Toward a Critical and Dialogical Model in Multicultural Social Justice Teacher Preparation. International Journal of Multicultural Education, 18(2), 125-142.

Covington, M., Chavis, T., \& Perry, A. (2017). A scholar-practitioner perspective to promoting minority success in STEM. Journal for Multicultural Education; Bingley, 11(2), 149-159.

Darder, A. (2015). Imagining justice: Politics, pedagogy, and dissent. In A. J. Jolivette (Ed.), Research Justice: Methodologies for Social Change (pp. 13-26). Bristol, Unitd Kingdom; Policy Press.

Dweck, C. S. (1999). Self-theories: Their Role in Motivation, Personality, and Development (1st ed.). New York: Psychology Press.

Dweck, C. S. (2008). Mindsets and math/science achievement. New York, NY:

Carnegie Corporation of New York-Institute for Advanced Study Commission on Mathematics and Science Education. Retreived from: https://www.growthmindsetmaths.com/uploads/2/3/7/7/23776169/mindset_and_ math_science_achievement_-_nov_2013.pdf

Edwards, D. B. (2010). Critical pedagogy and democratic education: Possibilities for cross-pollination. The Urban Review, 42(3), 221-242.

Espinosa, L. (2011). Pipelines and pathways: Women of color in undergraduate STEM majors and the college experiences that contribute to persistence. Harvard Educational Review, 81(2), 209-241.

Franklin, J. D. (2019). Coping with racial battle fatigue: Differences and similarities for African American and Mexican American college students. Race Ethnicity and Education, 22(5), 589-609. 
Journal Committed to Social Change on Race and Ethnicity | Volume 5, Issue 2 | 2019

Freire, P. (2018). Pedagogy of the Oppressed: 50th Anniversary Edition (4th ed.). New York: Bloomsbury Publishing USA.

Harnish, R., \& Bridges, K. (2011). Effect of syllabus tone: Students' perceptions of instructor and course. Social Psychology of Education, 14(3), 319-330.

Harris, F., \& Wood, J. L. (2013). Student success for men of color in community colleges: A review of published literature and research, 1998-2012. Journal of Diversity in Higher Education, 6(3), 174-185.

Hazari, Z., Sadler, P. M., \& Sonnert, G. (2013). The science identity of college students: Exploring the intersection of gender, race, and ethnicity. Journal of College Science Teaching, 42(5), 82-91.

Hurtado, S., Alvarado, A. R., \& Guillermo-Wann, C. (2015). Creating inclusive environments: The mediating effect of faculty and staff validation on the relationship between discrimination/bias to student's sense of belonging. Journal Committed to Social Change on Race and Ethnicity, 1(1), 59-81.

Johns, M., Schmader, T., \& Martens, A. (2005). Knowing is half the battle. Psychological Science, 16(3), 175-179.

Johnson, A. C. (2007). Unintended consequences: How science professors discourage women of color. Science Education, 91(5), 805-821.

Johnson, D. R. (2012). Campus racial climate perceptions and overall sense of belonging among racially diverse women in STEM majors. Journal of College Student Development; Baltimore, 53(2), 336-346.

King, B. T., \& Ford, T. E. (2003). African-American student perceptions of predominately White campuses: The importance of institutional characteristics relating to racial climate. Journal of Applied Sociology, os-20(2), 65-76.

Lalayants, M. (2012). Overcoming graduate students' negative perceptions of statistics. Journal of Teaching in Social Work, 32(4), 356-375.

Leonard, J., \& Moore, C. M. (2014). Learning to enact social justice pedagogy in mathematics classrooms. Action in Teacher Education (Association of Teacher Educators), 36(1), 76-95. 
Journal Committed to Social Change on Race and Ethnicity | Volume 5, Issue 2 | 2019

Lundberg, C. A., \& Schreiner, L. A. (2004). Quality and frequency of faculty-student interaction as predictors of learning: An analysis by student race/ethnicity. Journal of College Student Development, 45(5), 549-565.

McArthur, J. (2010). Achieving social justice within and through higher education: The challenge for critical pedagogy. Teaching in Higher Education, 15(5), 493-504.

McWilliams, S. (2015). The democratic syllabus. PS: Political Science \& Politics, 48(1), 167-170.

National Science Foundation. (2018). Higher education in science and engineering. Retrieved from https://www.nsf.gov/statistics/2018/nsb20181/report

Palmer, M. S., Wheeler, L. B., \& Aneece, I. (2016). Does the document matter? The evolving role of syllabi in higher education. Change, 48(4), 36-47.

Parson, L. (2016). Are STEM syllabi gendered? A feminist critical discourse analysis. The Qualitative Report; Fort Lauderdale, 21(1), 102-116.

Rankin, S. R., \& Reason, R. D. (2005). Differing perceptions: How students of color and White students perceive campus climate for underrepresented groups. Journal of College Student Development; Baltimore, 46(1), 43-61.

Saucerman, J., \& Vasquez, K. (2014). Psychological barriers to STEM participation for women over the course of development. Adultspan Journal, 13(1), 46-64.

Smith, J. L., Cech, E., Metz, A., Huntoon, M., \& Moyer, C. (2014). Giving back or giving up: Native American student experiences in science and engineering. Cultural Diversity and Ethnic Minority Psychology, 20(3), 413-429.

Smith, T., Brumskill, R., Johnson, A., \& Zimmer, T. (2018). The impact of teacher language on students' mindsets and statistics performance. Social Psychology of Education, 21(4), 775-786.

Solorzano, D., Ceja, M., \& Yosso, T. (2000). Critical race theory, racial microaggressions, and campus racial climate: The experiences of African American college students. Journal of Negro Education, 69(1/2), 60-73.

Spitzer, B., \& Aronson, J. (2015). Minding and mending the gap: Social psychological interventions to reduce educational disparities. British Journal of Educational Psychology, 85(1), 1-18. 
Journal Committed to Social Change on Race and Ethnicity | Volume 5, Issue 2 | 2019

Steele, C. M. (2011). Whistling Vivaldi: How stereotypes affect us and what we can do. New York; W. W. Norton \& Company.

Stephens, N. M., Townsend, S. S. M., Markus, H. R., \& Phillips, L. T. (2012). A cultural mismatch: Independent cultural norms produce greater increases in cortisol and more negative emotions among first-generation college students. Journal of Experimental Social Psychology, 48(6), 1389-1393.

Stieha, V. (2010). Expectations and experiences: The voice of a first-generation firstyear college student and the question of student persistence. International Journal of Qualitative Studies in Education, 23(2), 237-249.

Strayhorn, T. L., Long, L. L., Kitchen, J. A., Williams, M. S., \& Stenz, M. E. (2013). Academic and social barriers to Black and Latino male collegians' success in engineering and related STEM fields. Presented at the 120th ASEE Annual Conference and Exposition, Atlanta, GA.

Sulik, G., \& Keys, J. (2014). "Many students really do not yet know how to behave!": The syllabus as a tool for socialization. Teaching Sociology, 42(2), 151-160.

Thompson, B. (2007). The syllabus as a communication document: Constructing and presenting the syllabus. Communication Education, 56(1), 54-71.

Wasley, P. (2008). The syllabus becomes a repository of legalese. Chronicle of Higher Education, 54(27), A1-A10.

Williams, M. M., \& George-Jackson, C. E. (2014). Using and doing science: Gender, self-efficacy, and science identity of undergraduate students in STEM. Journal of Women and Minorities in Science and Engineering, 20(2), 99-126. 


\section{Appendix A}

The Social Justice Syllabus Design Tool with framework themes, literature references, and focus areas.

\begin{tabular}{|c|c|c|c|c|}
\hline Reflection Question & Reflection Notes & $\begin{array}{l}\text { Literature } \\
\text { Support }\end{array}$ & $\begin{array}{c}\text { Framework } \\
\text { Theme(s) }\end{array}$ & Focus Area(s) \\
\hline $\begin{array}{l}\text { 1. Does it tell students' how/why the } \\
\text { course content is relevant to their lives } \\
\text { and to their future careers? }\end{array}$ & & $\begin{array}{l}\text { - Thompson } \\
(2007)\end{array}$ & $\begin{array}{ll} & \text { Syllabi Best } \\
& \text { Practices } \\
\text { - } & \text { Stereotype } \\
\text { Threat } \\
\text { Interventions }\end{array}$ & Community \\
\hline $\begin{array}{l}\text { 2. Does it tell students how course } \\
\text { content or skills are used to improve } \\
\text { the lives of individuals and/or } \\
\text { communities? What are some of the } \\
\text { social justice implications of the class? }\end{array}$ & & $\begin{array}{ll}\text { - } & \text { Adams \& } \\
& \text { Love (2009) }\end{array}$ & $\begin{array}{ll}\text { - } & \text { Syllabi Best } \\
& \text { Practices } \\
\text { - } & \text { Social Justice } \\
& \text { Pedagogy } \\
& \text { Principles } \\
\end{array}$ & Community \\
\hline $\begin{array}{l}\text { 3. Is grading described in a way that is } \\
\text { success-oriented rather than failure- } \\
\text { oriented? Growth versus fixed } \\
\text { mindset? }\end{array}$ & & $\begin{array}{l}\text { - Sulik \& Keys } \\
(2014) \\
\text { - Thompson } \\
\text { (2007) }\end{array}$ & $\begin{array}{l}\text { - } \text { Syllabi Best } \\
\text { Practices } \\
\text { - } \quad \text { Stereotype } \\
\text { Threat } \\
\text { Interventions }\end{array}$ & Process \\
\hline $\begin{array}{l}\text { 4. Are there low-stakes assignments that } \\
\text { allow students to practice new skills } \\
\text { without much pressure? }\end{array}$ & & - Dweck (1999) & $\begin{array}{ll}\text { - } & \text { Syllabi Best } \\
\text { Practices } \\
\text { - } \quad \text { Stereotype } \\
\text { Threat } \\
\text { Interventions }\end{array}$ & Process \\
\hline $\begin{array}{l}\text { 5. Is there any language that suggests } \\
\text { that the content/skills of the class are } \\
\text { learned qualities rather than fixed } \\
\text { skills? (growth versus fixed mindset } \\
\text { triggers) }\end{array}$ & & $\begin{array}{l}\text { - Dweck (1999, } \\
\text { 2008) }\end{array}$ & $\begin{array}{l}\text { - Stereotype } \\
\text { Threat } \\
\text { Interventions }\end{array}$ & Process \\
\hline $\begin{array}{l}\text { 6. How are the assignments described? } \\
\text { Is the rationale for each assignment } \\
\text { clear so that students understand why } \\
\text { they are doing them? From a student's }\end{array}$ & & $\begin{array}{l}\text { - Thompson } \\
(2007)\end{array}$ & $\begin{array}{l}\text { - Syllabi Best } \\
\text { Practices }\end{array}$ & Relationship \\
\hline
\end{tabular}




\begin{tabular}{|c|c|c|c|c|}
\hline Reflection Question & Reflection Notes & $\begin{array}{l}\text { Literature } \\
\text { Support }\end{array}$ & $\begin{array}{l}\text { Framework } \\
\text { Theme(s) }\end{array}$ & Focus Area(s) \\
\hline \multicolumn{5}{|l|}{$\begin{array}{l}\text { perspective, do any of the } \\
\text { assignments seem like "busy work?" }\end{array}$} \\
\hline $\begin{array}{l}\text { 7. Do some of the readings come from } \\
\text { diverse authors? Can you foreground } \\
\text { this by including full names and/or } \\
\text { short bios or descriptions of some of } \\
\text { the readings and authors? }\end{array}$ & & $\begin{array}{l}\text { - Spitzer \& } \\
\text { Aronson } \\
(2015)\end{array}$ & $\begin{array}{l}\text { - } \text { Stereotype } \\
\text { Threat } \\
\text { Interventions } \\
\text { - Social Justice } \\
\text { Pedagogy } \\
\text { Principles }\end{array}$ & Community \\
\hline $\begin{array}{l}\text { 8. Have you included language from the } \\
\text { ethical codes of your profession or } \\
\text { statements about the social justice } \\
\text { commitments of your field? }\end{array}$ & & $\begin{array}{ll}\text { - } & \text { Adams \& } \\
\text { Love (2009) } \\
\text { - Thompson } \\
\text { (2007) }\end{array}$ & 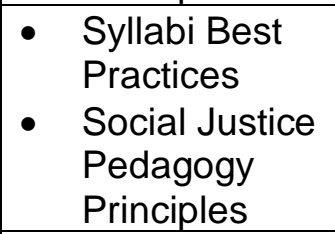 & Community \\
\hline $\begin{array}{l}\text { 9. Do you use communal language ("we," } \\
\text { "us) as opposed to individual language } \\
\text { ("you" and "I")? Does the "we" } \\
\text { language truly convey some } \\
\text { egalitarianism or merely mask the } \\
\text { power structure of the class? }\end{array}$ & & $\begin{array}{l}\text { - Sulik \& Keys } \\
\text { (2014) } \\
\text { - Thompson } \\
(2007)\end{array}$ & $\begin{array}{ll}\text { - } & \text { Syllabi Best } \\
\text { Practices } \\
\text { - Social Justice } \\
\text { Pedagogy } \\
\text { Principles } \\
\text { - Stereotype } \\
\text { Threat } \\
\text { Interventions } \\
\end{array}$ & $\begin{array}{l}\text { Relationship } \\
\quad \& \\
\text { Community }\end{array}$ \\
\hline $\begin{array}{l}\text { 10. Is there language that validates } \\
\text { students' experiences and feelings of } \\
\text { anxiety about the course and offers } \\
\text { assurances of resources to support } \\
\text { student learning? }\end{array}$ & & $\begin{array}{l}\text { - Lalayants } \\
(2012)\end{array}$ & $\begin{array}{l}\text { - Syllabi Best } \\
\text { Practices }\end{array}$ & Relationship \\
\hline $\begin{array}{l}\text { 11. Does the wording convey that you are } \\
\text { available to students as a resource? }\end{array}$ & & $\begin{array}{ll}\text { - Thompson } \\
\text { (2007) }\end{array}$ & 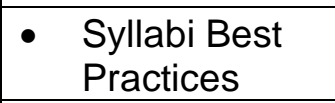 & Relationship \\
\hline $\begin{array}{l}\text { 12. Do you provide links to other } \\
\text { resources that may support learning, } \\
\text { such as videos, tutoring labs, study } \\
\text { groups, etc.? }\end{array}$ & & $\begin{array}{l}\text { - Sulik \& Keys } \\
(2014)\end{array}$ & $\begin{array}{l}\text { - Syllabi Best } \\
\text { Practices }\end{array}$ & Relationship \\
\hline $\begin{array}{l}\text { 13. Overall, does the syllabus have a } \\
\text { warm and inviting tone? }\end{array}$ & & $\begin{array}{ll}\text { - } & \text { Harnish \& } \\
& \text { Bridges }\end{array}$ & $\begin{array}{ll}\text { - } & \text { Syllabi Best } \\
& \text { Practices }\end{array}$ & $\begin{array}{l}\text { Relationship } \\
\&\end{array}$ \\
\hline
\end{tabular}




\begin{tabular}{|c|c|c|c|c|}
\hline Reflection Question & Reflection Notes & $\begin{array}{c}\text { Literature } \\
\text { Support }\end{array}$ & $\begin{array}{c}\text { Framework } \\
\text { Theme(s) }\end{array}$ & Focus Area(s) \\
\hline & & $\begin{array}{l}\text { (2011) } \\
\text { Sulik \& Keys } \\
(2014)\end{array}$ & $\begin{array}{l}\text { - Stereotype } \\
\text { Threat } \\
\text { Interventions }\end{array}$ & Community \\
\hline $\begin{array}{l}\text { 14. Are there technical terms or jargon } \\
\text { that the students may not yet have } \\
\text { encountered in their classes? }\end{array}$ & & $\begin{array}{l}\text { Lalayants } \\
(2012)\end{array}$ & $\begin{array}{l}\text { - Syllabi Best } \\
\text { Practices }\end{array}$ & $\begin{array}{l}\text { Community } \\
\& \\
\text { Process }\end{array}$ \\
\hline $\begin{array}{l}\text { 15. Does the syllabus read like a legal } \\
\text { document or legal contract? If so, are } \\
\text { all the "rules" necessary? }\end{array}$ & & - Wasley (2008) & $\begin{array}{ll}\text { - } & \text { Syllabi Best } \\
& \text { Practices } \\
\text { - } & \text { Stereotype } \\
\text { Threat } \\
\text { Interventions } \\
\end{array}$ & $\begin{array}{l}\text { Relationship } \\
\text { \& } \\
\text { Community }\end{array}$ \\
\hline $\begin{array}{l}\text { 16. Is there any language that might } \\
\text { prompt comparisons about groups' } \\
\text { ability levels, math skills, or other } \\
\text { differences that might trigger } \\
\text { stereotype threat? }\end{array}$ & & $\begin{array}{l}\text { - Spitzer \& } \\
\text { Aronson } \\
(2015)\end{array}$ & $\begin{array}{l}\text { - Stereotype } \\
\text { Threat } \\
\text { Interventions }\end{array}$ & Community \\
\hline $\begin{array}{l}\text { 17. Do any of the assignments, readings, } \\
\text { or topics on the schedule indicate how } \\
\text { power and privilege are addressed in } \\
\text { the class via readings, activities, and } \\
\text { topics? Is this part of the class } \\
\text { description? }\end{array}$ & & $\begin{array}{l}\text { - Convertino } \\
(2016)\end{array}$ & $\begin{array}{l}\text { - Social Justice } \\
\text { Pedagogy } \\
\text { Principles }\end{array}$ & Relationship \\
\hline $\begin{array}{l}\text { 18. Do you have any guest speakers, } \\
\text { films, or activities that offer students } \\
\text { with diverse role-models? }\end{array}$ & & $\begin{array}{l}\text { - } \text { Spitzer \& } \\
\text { Aronson } \\
(2015) \\
\end{array}$ & $\begin{array}{ll}\text { - Stereotype } \\
\text { Threat } \\
\text { Interventions }\end{array}$ & Community \\
\hline $\begin{array}{l}\text { 19. Does the syllabus describe a } \\
\text { democratic classroom? For example, } \\
\text { do descriptions of activities and } \\
\text { assignments offer any choice in topics } \\
\text { or formats? Any discussion of } \\
\text { negotiated rules? }\end{array}$ & & $\begin{array}{l}\text { - Thompson } \\
\text { (2007) }\end{array}$ & $\begin{array}{l}\text { - Social Justice } \\
\text { Pedagogy } \\
\text { Principles }\end{array}$ & Community \\
\hline
\end{tabular}

